\title{
Hospitalization of Diabetic Patients: Characteristics, Reasons for Admission: A Retrospective Study in a Tertiary University Hospital
}

\author{
Özge ÖZER ๑, Fatma Belgin EFE ๑, Bilge BAŞDOĞAN ๑, Aysen AKALIN ๑, Medine Nur KEBAPÇI ๑, \\ Göknur YORULMAZ (1)
}

Eskişehir Osmangazi University Faculty of Medicine, Department of Internal Diseases, Division of Endocrinology, Eskişehir, Turkey

Cite this article as: Özer Ö, Efe FB, Başdoğan B, Akalın A, Kebapçı MN, Yorulmaz G. Hospitalization of Diabetic Patients: Characteristics, Reasons for Admission: A Retrospective Study in a Tertiary University Hospital. Turk J Diab Obes 2021;1: 33-42.

\begin{abstract}
Aim: In this study, we examined the reasons for hospitalization and general characteristics of patients diagnosed with diabetes.

Material and Methods: Data of 209 patients who were admitted to the endocrinology service of Osmangazi University between January 1 and December 31, 2019 were compiled retrospectively from medical records.

Results: 134 (64\%) of patients were female and 75 (36\%) were male. Median age of women was 57 and men were 55. Median length of hospitalization was 10 days in patients, duration of diabetes was 13 years in women and 10 years in men. Nephropathy (71 patients) and retinopathy (65 patients) were found to be more common among the complications of diabetes, in our study. Nephropathy and retinopathy were more common among chronic complications of diabetes. Patients were divided into five categories according to their hospitalization reasons: hyperglycemia, diabetic ketoacidosis, hyperglycaemic hyperosmolar state, hypoglycemia and other causes (adrenal adenoma, anemia etiology, hypertension etiology and hypercalcemia evaluation). The most common reason for hospitalization was hyperglycemia (109 patients). The patients in this group were those with a fasting blood glucose above $140 \mathrm{mg} / \mathrm{dl}$ and postprandial blood glucose above $180 \mathrm{mg} / \mathrm{dl}$ during home blood glucose monitoring, despite appropriate treatment steps. 50 patients also had infection in the initial assessment. These infections were urinary tract infections, pneumonia, diabetic foot and upper respiratory tract infections. There were no patients with more than one focus of infection.

Conclusion: The number of patients with diabetes is increasing worldwide and in our country. This increases complications and cost of diabetes directly and indirectly. Understanding the characteristics of hospitalized diabetic patients provides successful management of these patients.
\end{abstract}

Key Words: Diabetes mellitus, Complication, Hospitalization

\section{Diyabet Hastalarının Sık Yatış Nedenleri ve Genel Özelliklerinin İncelenmesi: Üçüncü Basamak Üniversite Hastanesinde Retrospektif Bir Çalışma}

ÖZ

Amaç: Bu çalışmada diabetes mellitus tanılı hastaların hastaneye yatırılmasındaki nedenleri, hastaların karakteristik özelliklerini, diyabetik komplikasyonlarının ortaya konulmasını amaçladık.

Gereç ve Yöntemler: Çalışmamızda 1 Ocak 2019 ve 31 Aralık 2019 tarihleri arasında Eskişehir Osmangazi Üniversitesi Tıp Fakültesi hastanesi endokrinoloji servisine diyabet tanısı olup yatışı yapılan 209 hastanın verileri retrospektif olarak tıbbı kayıtlardan derlenmiştir.

Bulgular: Hastaların 134 (\%64)'ü kadın, 75 (\%36)'i erkek olarak görüldü. Kadınların ortanca yaşı 57, erkeklerin 55 idi. Hastanede yatış sürelerinin kadınlarda ve erkeklerde ortanca değerin 10 gün, diyabet sürelerinin ise kadınlarda 13 yıl, erkeklerde 10 yıl olduğu görüldü. Diyabetin komplikasyonlarına bakıldığında nefropati (71 hasta) ve retinopati (65 hasta) daha sıktı. Hastalar yatış nedenlerine göre hiperglisemi, diyabetik ketoasidoz, hiperosmolar hiperglisemik durum, hipoglisemi ve diğer nedenler olmak üzere beş temel kategoriye ayrıldı. Diğer nedenler içinde diyabet dışında adrenal adenom değerlendirme, hipertansiyon etiyolojisi arama gibi yatı̧̧ 
nedenleri vardı. En çok yatış nedeni 109 hastada görülen hiperglisemiydi. Hiperglisemi nedeniyle yatan hastaların yatırılma amacı, uygun tedavi basamaklarının uygulanmasına rağmen evde kan şekeri takiplerinde açlık kan şekeri 140 mg/dl üzeri, tokluk kan şekeri $180 \mathrm{mg} / \mathrm{dl}$ üzeri olan hastaların kan şeker regülasyonunu sağlamaktı. Toplam 50 hasta ilk yatış değerlendirmesinde enfeksiyona da sahipti. Bu enfeksiyonların idrar yolu enfeksiyonu, pnömoni, diyabetik ayak ve üst solunum yolu enfeksiyonları olduğu görüldü. Birden fazla enfeksiyon odağının görüldüğ̈̈ hasta yoktu.

Sonuç: Dünya genelinde ve ülkemizde diyabet tanılı hasta sayısında görülen artış, komplikasyonların oranında da artışı beraberinde getirmektedir. $\mathrm{Bu}$ durum diyabetin maliyetini doğrudan ve dolaylı olarak artırmaktadır. Hastanede yatan diyabetik hastaların karakteristik özellikleri ve başvuru nedenlerindeki farklılıkları anlamak, bu hastaların başarılı bir şekilde yönetilmelerine de ışık tutacaktır.

Anahtar Sözcükler: Diabetes mellitus, Komplikasyon, Hospitalizasyon

\section{INTRODUCTION}

Diabetes mellitus is a group of metabolic diseases. Defect of insulin secretion, insulin action, or both can cause hyperglycemia (1). Type 1 diabetes mellitus, type 2 diabetes mellitus, other specific forms of diabetes and gestational diabetes mellitus are evaluated in 4 basic categories (2). Many chronic complications of diabetes can be seen in patients with long-term and uncontrolled diabetes (3). These are considered as microvascular (retinopathy, nephropathy, neuropathy) and macrovascular (coronary artery disease, cerebrovascular event, peripheral artery disease) complications (4). Acute coronary syndrome, a history of myocardial infarction (MI), stroke, and peripheral arterial disease are accepted as atherosclerotic cardiovascular disease (ASCVHD). In addition to chronic complications, acute complications also cause serious mortality and morbidity. These are diabetic ketoacidosis (DKA), hyperosmolar hyperglycemic state (HHD), hypoglycemia.

According to the data published by the international diabetes federation, approximately one in 11 adults is diagnosed with diabetes. About three quarters of these live in low-income and middle-income countries (5). Due to factors such as changing lifestyles and technological developments, there has been an increase in the number of patients with diabetes worldwide in the last forty years (6).

There is an increase in the number of diabetic patients and the rate of complications in the world and in our country. This situation brings an economic burden. Understanding the characteristics of hospitalized diabetic patients provides successful management of these patients. There is a lack of information about the extent to which chronic complications of diabetes affect acute complications in the literature. In this study, the reasons for the hospitalization of patients with diabetes mellitus, the characteristics of the patients and their diabetic complications were investigated.

\section{MATERIALS and METHODS}

Our study is a retrospective study. Between January 2019 and December 2019, the data of 209 patients who were diag- nosed with diabetes mellitus and hospitalized in Eskisehir Osmangazi University Faculty of Medicine, Department of Endocrinology, were collected retrospectively from medical records. The clinical data of the patients included sex, length of hospital stay, Hbalc level, duration of diabetes mellitus, complications (retinopathy, nephropathy, neuropathy, coronary artery disease, and cerebrovascular event).

Retinopathy was detected by the ophthalmology department. Microalbumin level was measured in 24 -hour urine collected from patients for nephropathy and glomerular filtration rate was calculated. Neuropathy scans were performed with neurological physical examination, and clinical tests such as 10 grams of compression monofilament and diapason. Reasons for hospitalization; hyperglycemia, diabetic ketoacidosis, hyperosmolar hyperglycemic state, hypoglycemia and other causes were discussed in five basic categories. The infection status of the patients during their hospitalization was also examined. This was evaluated in five categories as urinary tract infection, pneumonia, diabetic foot, upper respiratory tract infection and absence of infection.

The study was approved by the ethics committee of Eskişehir Osmangazi University (E-25403353-05.99-68801).

\section{Statistical Analysis}

Statistical Packages for the Social Sciences version 23.0 (SPSS Inc. Chicago, IL) software was used for all statistical analyzes in our study. Significant level was accepted as $\mathrm{p}<0.05$ in statistical comparisons. In the evaluation of the study data, descriptive statistical methods (mean, standard deviation, median, frequency, ratio, interquartile IQR) as well as the Fisher, Pearson and Yates test were used to compare qualitative data. CHAID analysis was performed.

\section{RESULTS}

The data of 209 diabetic patients hospitalized in 2019 were examined in Eskisehir Osmangazi University Faculty of Medicine Endocrinology Department service. 134 (64\%) of these patients were female and $75(36 \%)$ were male. The 
median age of women was 57 and the median age of men was 55 . There was no statistically significant difference between the two groups. Diabetes types included type 1 diabetes mellitus in 47 patients, type 2 diabetes mellitus in 150 patients, and gestational diabetes mellitus in 3 patients. Information of 9 patients was not available. It was observed that the median length of hospitalization of the patients was 10 days in women and men, and the duration of diabetes was 13 years in women and 10 years in men. There was no statistically significant difference between the two groups in terms of Hbalc values (Table 1).

Chronic complications of diabetes mellitus such as retinopathy, nephropathy, neuropathy, coronary artery disease and cerebrovascular event were evaluated. No statistically significant difference was found between male and female patients (Table 2).

The patients were divided into five basic categories according to the reasons for hospitalization: hyperglycemia, diabetic ketoacidosis, hyperosmolar hyperglycemic state (HHS), hypoglycemia and other causes (adrenal adenoma, anemia etiology, hypertension etiology and hypercalcemia evaluation). The number of patients in other causes was 18 (Table 3). The most common reason for hospitalization was hyperglycemia as $109(52.2 \%)$ patients. Patients in this group were those with a fasting blood glucose above $140 \mathrm{mg} /$ $\mathrm{dl}$ and postprandial blood glucose above $180 \mathrm{mg} / \mathrm{dl}$ during home blood glucose monitoring, despite appropriate treatment steps. Hyperglycemia was followed by diabetic ketoacidosis $(22.5 \%)$ and hypoglycemia (13\%). There was no statistically significant difference between the length of stay, duration of diabetes and the reasons for hospitalization.

We examined the first three most common reasons for hospitalization in terms of the frequency of chronic complications (Table 4). Diabetic retinopathy (p: 0.016) was observed in 11 patients in the hypoglycemia group (p: 0.044), and in 7 patients in the diabetic ketoacidosis group. These values were statistically significant.

Infection (inf) status of the patients was observed when they were admitted to the service (Table 5). Most of the patients (159 patients) did not have any signs of infection. 30 patients had urinary tract infection (UTI), 4 patients had pneumonia, 12 patients had diabetic foot, 4 patients

Table 1: General characteristics of the patients

\begin{tabular}{lccc}
\hline & Female & Male & p \\
\hline Age (Years) & $57(41-70)^{\star}$ & $55(47-67)^{\star}$ & 0.998 \\
\hline Length of hospitalization (Days) & $10(8-14)^{\star}$ & $10(7-16)^{\star}$ & 0.457 \\
\hline Hbalc (\%) & $9.1(7.6-11.4)^{\star}$ & $10(8-11.6)^{\star}$ & 0.127 \\
\hline Duration of diabetes mellitus (Year) & $13(7-20)^{\star}$ & $10(4-18)^{\star}$ & 0.193 \\
\hline
\end{tabular}

${ }^{*}$ median $(\mathrm{IQR})$

Table 2: Chronic complications of diabetes

\begin{tabular}{|c|c|c|c|c|}
\hline & Female & Male & All patients groups & $\mathbf{p}$ \\
\hline Retinopathy, n (\%) & & & & 0.248 \\
\hline Yes & $36(35.6)$ & $29(44.6)$ & $65(39.2)$ & \\
\hline No & $65(64.4)$ & $36(55.4)$ & $101(60.8)$ & \\
\hline Nephropathy, n (\%) & & & & 0.594 \\
\hline Yes & $44(36.4)$ & $27(40.3)$ & $71(37.8)$ & \\
\hline No & $77(63.6)$ & $40(59.7)$ & $117(62.2)$ & \\
\hline Neuropathy, n (\%) & & & & 0.313 \\
\hline Yes & $27(26.2)$ & $21(35)$ & $48(29.4)$ & \\
\hline No & $76(73.8)$ & $39(65)$ & $115(70.6)$ & \\
\hline Coronary artery disease, $\mathrm{n}(\%)$ & & & & 0.504 \\
\hline Yes & $31(24)$ & $14(18.9)$ & $45(22.2)$ & \\
\hline No & $98(76)$ & $60(81.1)$ & $158(77.8)$ & \\
\hline Cerebrovascular disease, $\mathrm{n}(\%)$ & & & & 1 \\
\hline Yes & $8(6.3)$ & $4(5.4)$ & $12(5.9)$ & \\
\hline No & $120(93.8)$ & $70(94.6)$ & $190(94.1)$ & \\
\hline
\end{tabular}


Table 3: Reasons for hospitalization of the patients

\begin{tabular}{|c|c|c|c|c|}
\hline & Female & Men & All patients groups & $\mathbf{p}$ \\
\hline Hyperglicemia, n (\%) & & & & 0.748 \\
\hline Yes & $71(53)$ & $38(50.7)$ & $109(52.2)$ & \\
\hline No & $63(47)$ & $37(49.3)$ & $100(47.8)$ & \\
\hline Diabetic ketoacidosis, n (\%) & & & & 0.572 \\
\hline No & $28(20.9)$ & $19(25.3)$ & $47(22.5)$ & \\
\hline Yes & $106(79.1)$ & $56(74.7)$ & $162(77.5)$ & \\
\hline Hyperosmolar hyperglycemic state, n (\%) & & & & 0.161 \\
\hline Yes & $5(3.8)$ & $0(0)$ & $5(2.4)$ & \\
\hline No & $127(96.2)$ & $75(100)$ & $202(97.6)$ & \\
\hline Hypoglycemia, n (\%) & & & & 0.758 \\
\hline Yes & $16(12.1)$ & $11(14.7)$ & $27(13)$ & \\
\hline No & $116(87.9)$ & $64(85.3)$ & $180(87)$ & \\
\hline Others, $\mathrm{n}(\%)$ & & & & 1 \\
\hline Yes & $11(8.3)$ & $7(9.3)$ & $18(8.7)$ & \\
\hline No & $121(91.7)$ & $68(90.7)$ & $189(91.3)$ & \\
\hline
\end{tabular}

Table 4: Causes of hospitalization and chronic complications

\begin{tabular}{|c|c|c|c|c|c|c|}
\hline & Hyperglicemia & p & Diabetic ketoacidosis & p & Hypoglycemia & p \\
\hline Retinopathy, $\mathrm{n}$ & & 0.076 & & 0.016 & & 0.044 \\
\hline Yes & 45 & & 7 & & 11 & \\
\hline No & 64 & & 40 & & 16 & \\
\hline Nephropathy, $\mathrm{n}$ & & 0.799 & & 0.555 & & 0.342 \\
\hline Yes & 42 & & 13 & & 10 & \\
\hline No & 67 & & 34 & & 17 & \\
\hline Neuropathy, $\mathrm{n}$ & & 0.936 & & 1 & & 0.228 \\
\hline Yes & 29 & & 10 & & 8 & \\
\hline No & 80 & & 37 & & 19 & \\
\hline Coronary artery disease, $\mathrm{n}$ & & 0.123 & & 0.058 & & 0.380 \\
\hline Yes & 29 & & 5 & & 8 & \\
\hline No & 80 & & 42 & & 19 & \\
\hline Cerebrovascular disease, $\mathrm{n}$ & & 0.585 & & 0.472 & & 0.650 \\
\hline Yes & 5 & & 4 & & 2 & \\
\hline No & 104 & & 43 & & 25 & \\
\hline
\end{tabular}

Table 5: Coexisting infection status during hospitalization

\begin{tabular}{lcccc}
\hline & Female & Male & All patients groups & p \\
\hline & & & & $\mathbf{0 . 2 6 4}$ \\
\hline Urinary tract infection, $\mathrm{n}(\%)$ & $23(17.2)$ & $7(9.3)$ & $30(14.4)$ & \\
\hline Pneumonia, $\mathrm{n}(\%)$ & $4(3)$ & $0(0)$ & $4(1.9)$ & \\
\hline Diabetic foot, $\mathrm{n}(\%)$ & $7(5.2)$ & $5(6.7)$ & $12(5.7)$ \\
\hline Upper respiratory tract infection, $\mathrm{n}(\%)$ & $2(1.5)$ & $2(2.7)$ & $4(1.9)$ & \\
\hline No infection, $\mathrm{n}(\%)$ & $98(73.1)$ & $61(81.3)$ & $159(76.1)$ \\
\hline
\end{tabular}


had upper respiratory tract infection (URTI). There was no patient with more than one focus of infection. There was no statistically significant difference between these groups.

We looked at the three most common reasons for hospitalization in terms of microvascular complications and infection states with CHAID analysis. Neuropathy and infection conditions were examined with the CART technique in patients with hypoglycemia (Figure 1). According to this; neuropathy was observed in $16.7 \%$ of those with hypoglycemia, and also UTI and URTI infections were observed in $13.3 \%$ of this group. Neuropathy was observed in $11.8 \%$ of those without hypoglycemia, and also UTI and URTI infections were observed in $12.8 \%$ of this group.

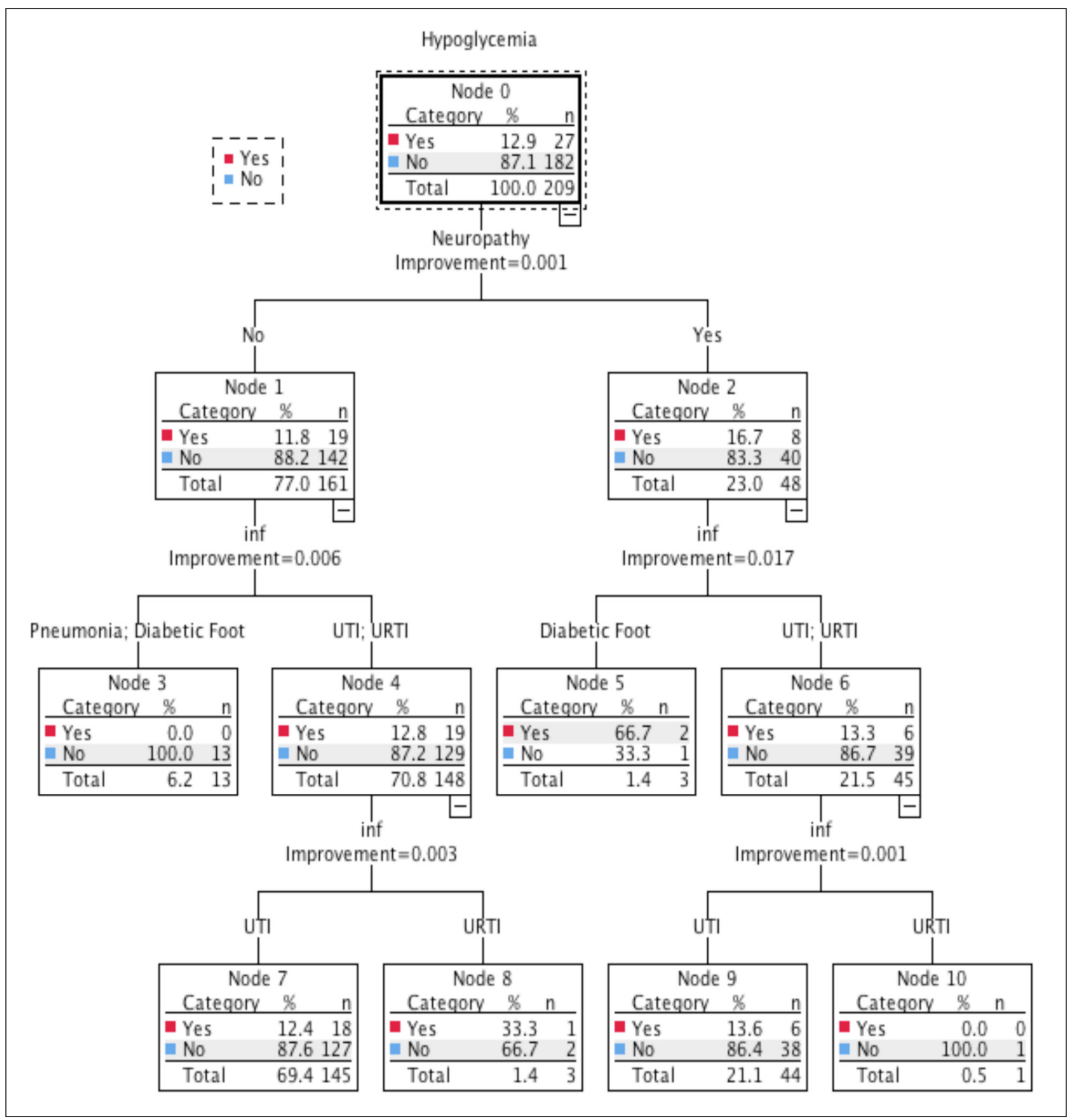

Figure 1. CHAID analysis chart for neuropathy and infection in patients with hypoglycemia. 
Retinopathy and infection cases were examined with the CART technique in hypoglycemia group. According to this; retinopathy was observed in $16.7 \%$ of those with hypoglycemia, and also UTI and diabetic foot were observed in $17.6 \%$ of this group. Retinopathy was observed in $8.3 \%$ of those without hypoglycemia, and also UTI and diabetic foot were observed in $7.6 \%$ of this group. Nephropathy and infection cases were examined with CART technique. According to this; nephropathy was observed in $14.1 \%$ of those with hypoglycemia, and also UTI, Pneumonia and diabetic foot were observed in $12.9 \%$ of this group. Nephropathy was observed in $11.0 \%$ of those without hypoglycemia, and also UTI infection was observed in $11.4 \%$ of this group.
Nephropathy and infections were investigated in patients with hyperglycemia with the CART technique (Figure 2). According to this; nephropathy was observed in $59.2 \%$ of those with hyperglycemia, and also UTI and pneumonia infections were observed in $62.1 \%$ of this group. Nephropathy was observed in $52.8 \%$ of those without hyperglycemia, and also UTI and pneumonia infection were observed in $56.9 \%$ of this group.

Neuropathy and infection conditions were examined with the CART technique in those with hyperglycemia (Figure 3). According to this; Neuropathy was observed in $60.4 \%$ of those with hyperglycemia, and also UTI infections were observed in $65.9 \%$ of this group. Neuropathy was observed

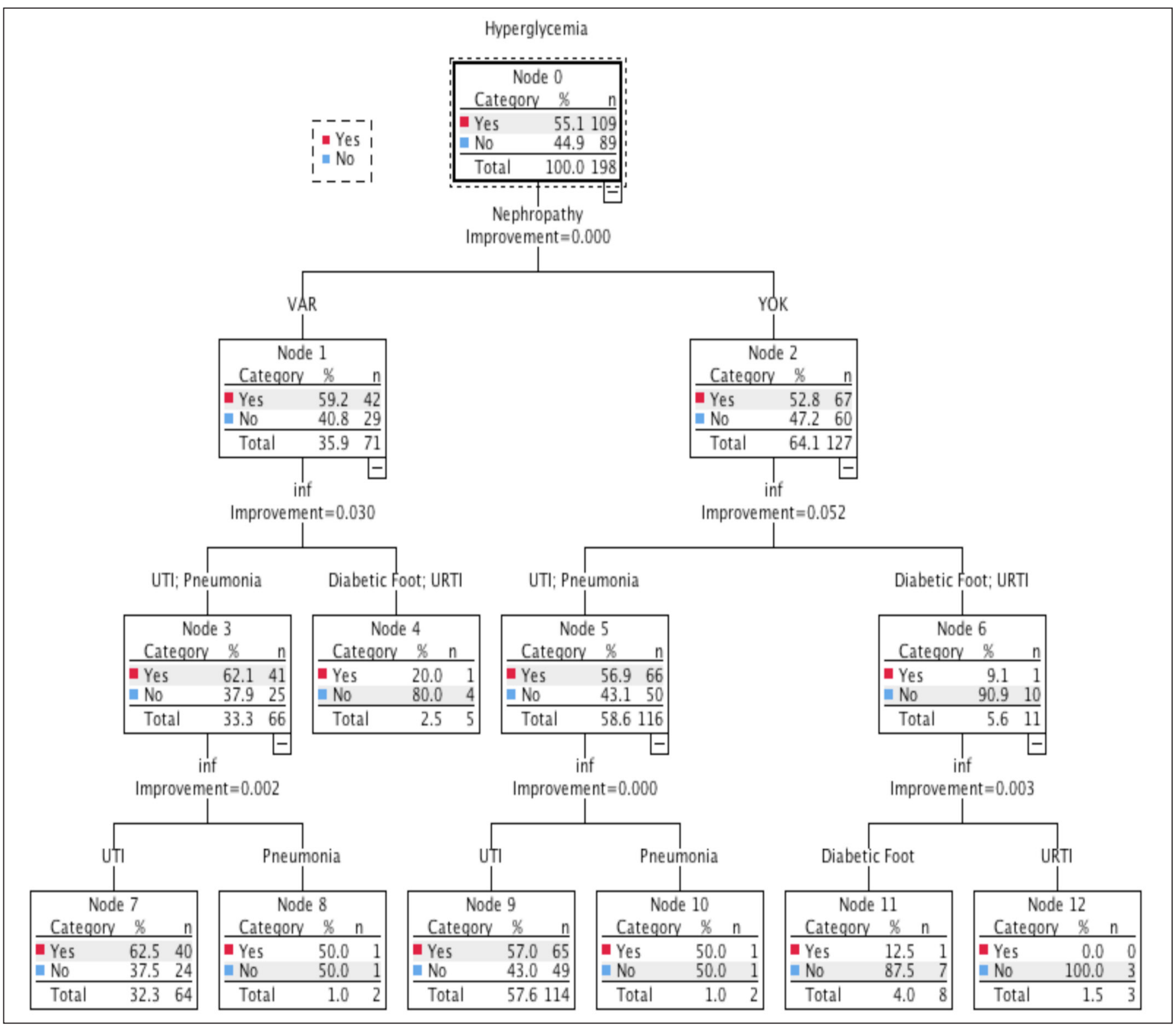

Figure 2. CHAID analysis chart for nephropathy and infection in patients with hyperglycemia. 
in $49.7 \%$ of those without hyperglycemia, and also UTI and pneumonia infection were observed in $52.3 \%$ of this group.

Retinopathy and infection cases were examined with the CART technique in patients with hyperglycemia (Figure 4). According to this; retinopathy was observed in $62.5 \%$ of those with hyperglycemia, and also UTI and pneumonia infections were observed in $69.8 \%$ of this group. Retinopa- thy was observed in $53.2 \%$ of those without hyperglycemia, and also in $55.2 \%$ of this group, UTI and diabetic foot were observed.

Retinopathy and infection cases were examined with CART technique in those with diabetic ketoacidosis. According to this; retinopathy was observed in $10.8 \%$ of those with diabetic ketoacidosis, and also UTI and pneumonia infec-

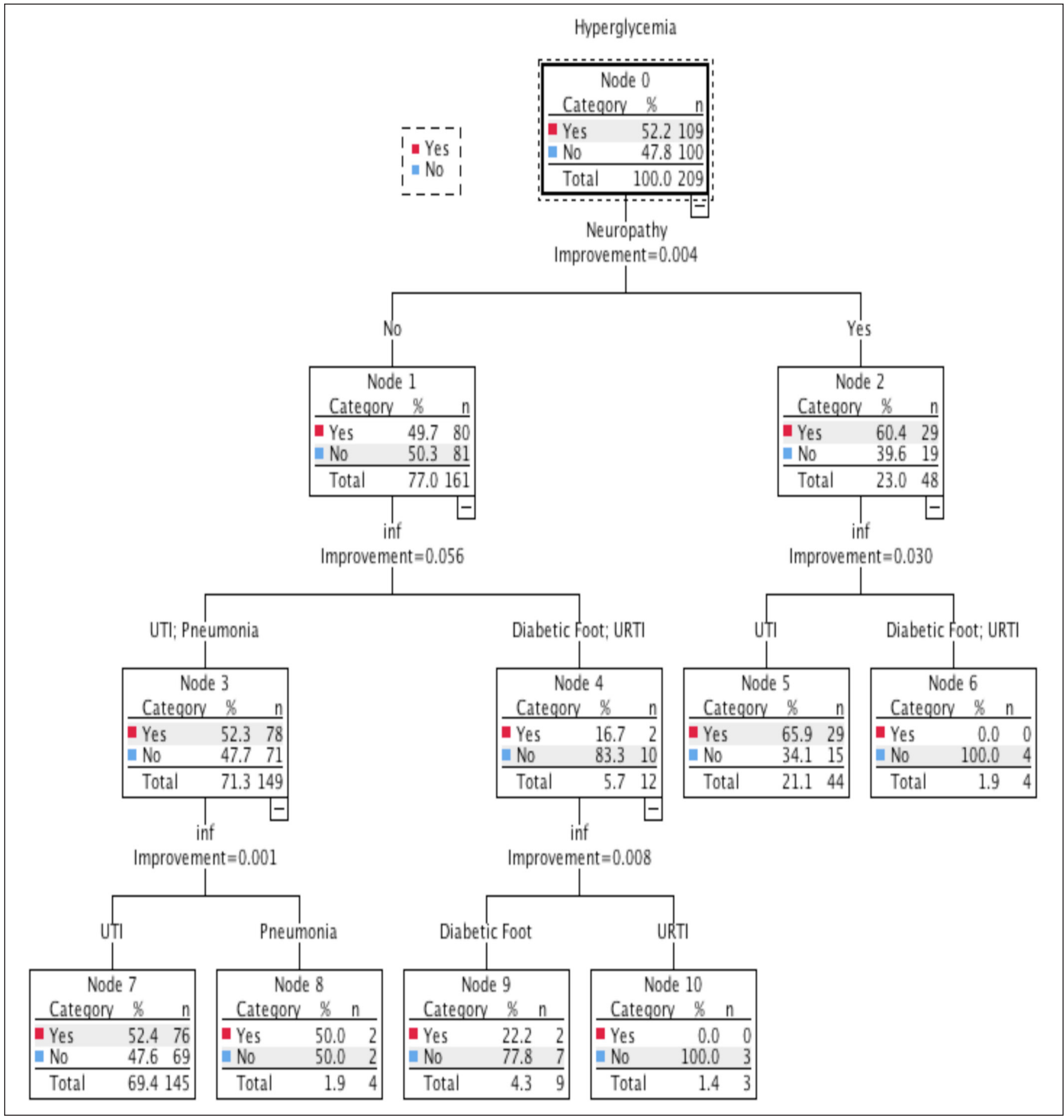

Figure 3. CHAID analysis chart for neuropathy and infection in patients with hyperglycemia. 
tions were observed in $9.8 \%$ of this group. Retinopathy was observed in $27.6 \%$ of those without diabetic ketoacidosis, and also UTI, pneumonia and diabetic foot were observed in $25.9 \%$ of this group. With the same technique, neuropathy was observed in $20.8 \%$ of those with diabetic ketoacidosis, and also UTI and diabetic foot were observed in 19.1\% of this group. Neuropathy was observed in $23.0 \%$ of those without diabetic ketoacidosis, and also UTI and pneumonia infection was observed in $20.8 \%$ of this group. Nephropathy and infection cases were examined with CART technique in diabetic ketoacidosis patients. According to this; nephropathy was observed in $18.3 \%$ of those with diabetic

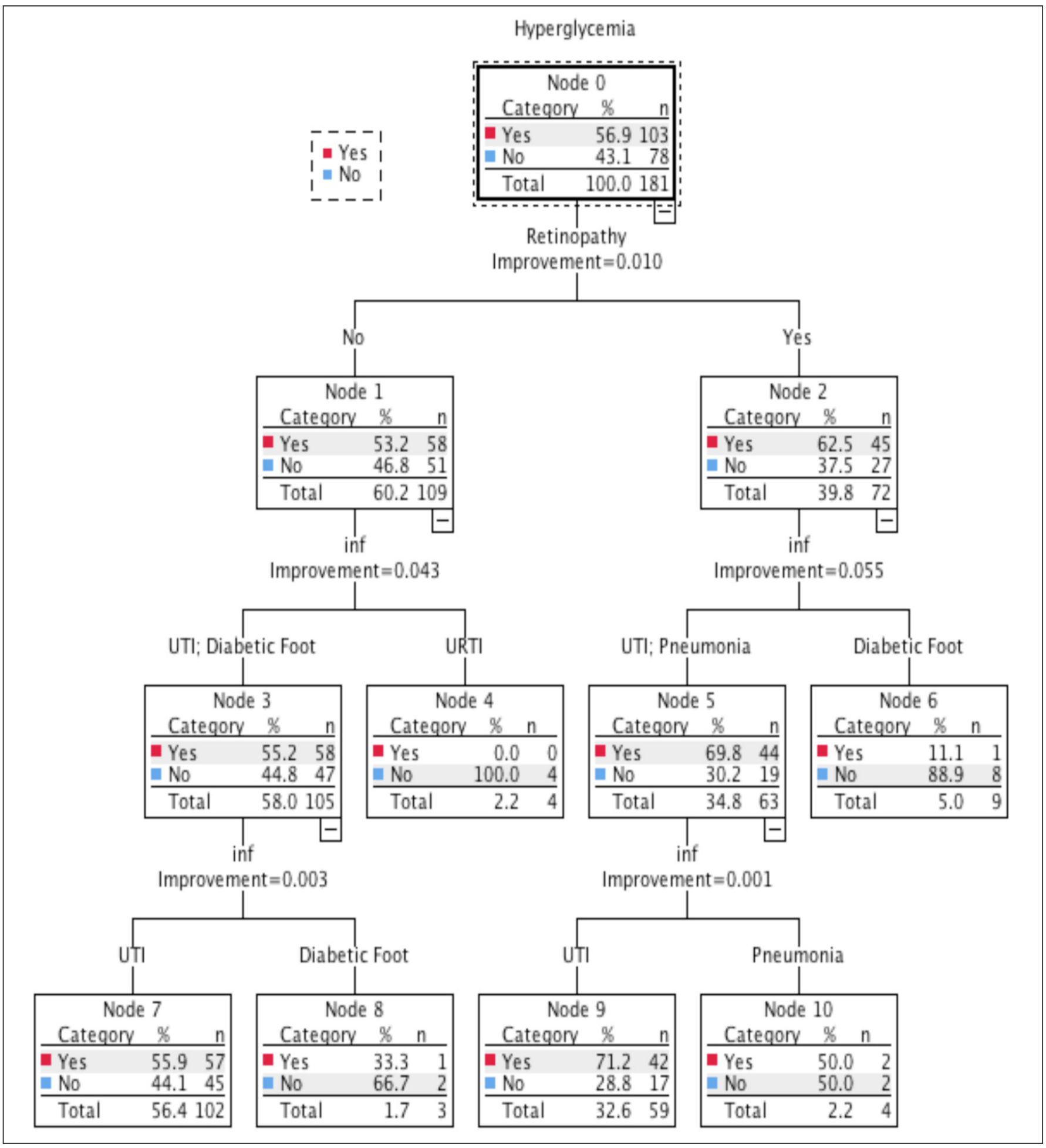

Figure 4. CHAID analysis chart for retinopathy and infection in patients with hyperglycemia. 
ketoacidosis, at the same time, UTI and soft tissue infections were observed in $19.1 \%$ of this group. Nephropathy were observed in $22.8 \%$ of those without diabetic ketoacidosis, and also UTI, pneumonia and diabetic foot were observed in $21.0 \%$ of this group.

\section{DISCUSSION}

In our study, we examined the general characteristics and reasons for hospitalization of patients diagnosed with diabetes. The most common reason for hospitalization was hyperglycemia (52.2\%). The reason for hospitalization of patients with hyperglycemia was to provide blood glucose regulation due to fasting blood glucose values above $140 \mathrm{mg} / \mathrm{dl}$ and postprandial blood glucose above $180 \mathrm{mg} /$ $\mathrm{dl}$ despite the treatment options applied in outpatient follow-ups. Hyperglycemia was followed by diabetic ketoacidosis and hypoglycemia. There was no significant difference between these groups for gender. In a study with a geriatric patient group, the reasons for hospitalization of the patients; chronic complications, hyperglycemia, hypoglycemia, neoplasms, infections, diabetic ketoacidosis and other diseases. The most common reason has been shown as chronic complications (7). In a study by Kardas and Ratajczyk-Pakalska, the most common reasons for admission to hospital were cardiovascular and respiratory diseases (8). In one study, the main causes of hospitalizations were shown as infections and chronic complications of diabetes in the lower extremities and cardiovascular system (9). In our study, chronic complications were not specified as a separate group. Because the departments' services are available separately in our hospital. For example, if diabetic nephropathy is the main reason for hospitalization, this patient is admitted to the nephrology department, and if there is any infection, the infection department. Most of the patients had no infection at presentation. This showed us that patients with symptoms such as infection and heart failure applied to other departments.

Diabetes mellitus is a global health problem. Turkey Diabetes, Hypertension, Obesity and Endocrinology Diseases Prevalence Study-II (TURDEP-II Study) were examined 20 years and older adults who were 26.499 people. It was observed that the diabetes prevalence in this group was $13.7 \%$. In this study, no significant difference was found between the prevalence of diabetes in urban and rural areas according to the TURDEP-1 study. Again, compared with the TURDEP-1 study, the prevalence of diabetes increased by about $90 \%$ in 12 years (10). In an another study, it was concluded that as the gross domestic product per capita increases, the prevalence of diabetes will decrease (11).

According to international diabetes federation data, it is predicted that there will be approximately 11.8 million patients with diabetes in 2035 (5). Studies show that there is a rapid increase in the rate of patients with diabetes. This situation is same for the complications of diabetes (12). On the other hand, diabetic ketoacidosis, hyperosmolar hyperglycemic state and hypoglycemia also constitute acute complications of diabetes. Diabetic ketoacidosis and hyperglycemic hyperosmolar state are serious acute metabolic complications caused by poor glycemic control. Severe hypoglycemic events may counteract the beneficial effects of intensive glycemic management strategies targeting normoglycemia in patients with diabetes mellitus (13).

Uncontrolled diabetes negatively affects the functions of cells in the immune system. That can cause some infections. This situation accelerates metabolic complications in diabetes (14). In this respect, it is very important to inform and educate patients about infections (15). The most common infections are such as osteomyelitis, pyelonephritis, cystitis, pneumonia, cellulitis (16). In a study with 150 diabetic patients, 46 percent of these had a diabetic foot infection (17). In our study, it was observed that infection accompanied the infection in the first evaluation of fifty patients during their hospitalization. While the most common urinary tract infection was followed by diabetic foot, pneumonia and upper respiratory tract infection. We have seen that these data are compatible with the literature.

In our study, retinopathy was found statistically significant in 7 of 47 patients presenting with diabetic ketoacidosis and in 11 of 27 patients presenting with hypoglycemia. We looked at the three most common reasons for hospitalization in terms of microvascular complications and infection states with CHAID analysis. According to these analyzes; remarkably, according to these analyzes, $59.2 \%$ of those with hyperglycemia had nephropathy, and $62.1 \%$ of this group also had UTI and pneumonia infections. Neuropathy was observed in $60.4 \%$ of those with hyperglycemia, and also UTI infections were observed in $65.9 \%$ of this group. Retinopathy was observed in $62.5 \%$ of those with hyperglycemia, and also UTI and Pneumonia infections were observed in $69.8 \%$ of this group. The higher prevalence of microvascular complications in the hyperglycemic group may indicate that long-term blood glucose level disturbances are more significant than acute disorders such as dka and hhs.

In a study with type 1 diabetes mellitus patients, it was shown that the severity of ketoacidosis at the time of diagnosis was not associated with subsequent lifetime $\mathrm{HbAlc}$ values and long-term microvascular complications (18). Tanaka et al. has been shown to have a history of severe hypoglycemia as an increased risk factor for diabetic retinopathy in diabetic patients (19). In a study, it has been shown that exposure to severe hypoglycemia has no effect on the frequency of devel- 
opment of retinopathy or nephropathy (20). More studies are needed to examine the direct relationship between acute complications and microvascular complications.

The limitations of our study are that it is a single center study. We could not find enough information from records regarding lifestyles and habits such as smoking and exercise.

In the light of our study, we tried to reveal the increasingly common causes of hospitalization in patients with diabetes mellitus. It is also hoped that survival, the quality of life of the patient will increase with appropriate treatment. It is also possible to contribute to the economy of the country.

Acknowledgements

The authors thank all the project participants for their contributions.

\section{Author Contributions}

Study concept / Design: Belgin Efe, Özge Özer, Data collecting: Özge Özer, Bilge Başdoğan, Data analysis and interpretation: Özge Özer, Göknur Yorulmaz, Post draft: Belgin Efe, Özge Özer, Critical review of the content: Belgin Efe, Nur Kebapçı, Aysen Akalın.

\section{Conflict of Interests}

The authors have no conflict of interests to declare.

\section{Financial Support}

There is no financial support for the study.

\section{Ethical Approval}

The study was approved by the ethics committee of Eskişehir Osmangazi University (E-25403353-05.99-68801).

Peer Review Process

Extremely reviewed and accepted.

\section{REFERENCES}

1. Türkiye Endokrinoloji ve Metabolizma Derneği. Diabetes Mellitus ve Komplikasyonlarının tanı, tedavi ve izlem kılavuzu. 2019. (Accessed February 10, 2021, at https://temd. org.tr/admin/uploads/tbl_kilavuz/201908190958542019tbl_ kilavuzb48da47363.pdf)

2. Roden M. Diabetes mellitus: Definition, classification and diagnosis. Wien Klin Wochenschr. 2016;128 Suppl 2:S37-40.

3. American Diabetes Association. Diagnosis and classification of diabetes mellitus. Diabetes Care. 2011;34 Suppl 1:S62-69.

4. Rangel ÉB, Rodrigues CO, de Sá JR. Micro- and macrovascular complications in diabetes mellitus: Preclinical and clinical studies. J Diabetes Res. 2019;2019:2161085.

5. Türk Diyabet Cemiyeti. IDF Diyabet Atlası Küresel Tahminleri, 2015 - 2040. 2015. (Accessed February 10, 2021, at from: http://www.diabetcemiyeti.org/c/diyabet-istatistikleri. )
6. The Lancet. Diabetes: A dynamic disease. Lancet (London, England). 2017;389(10085):2163.

7. Lin W, Chen C, Guan H, Du X, Li J. Hospitalization of elderly diabetic patients: Characteristics, reasons for admission, and gender differences. BMC Geriatr. 2016;16:160.

8. Kardas P, Ratajczyk-Pakalska E. Reasons for elderly patient hospitalization in departments of internal medicine in Lodz. Aging Clin Exp Res. 2003;15(1):25-31.

9. Haifa Elhadi A, Faiza H. Reasons for admission of individual with diabetes to the Tripoli Medical Center in 2015. Diabetes Metab Syndr. 2019;13(4):2571-2578.

10. Satman I, Omer B, Tutuncu Y, Kalaca S, Gedik S, Dinccag N, Karsidag K, Genc S, Telci A, Canbaz B, Turker F, Yilmaz T, Cakir B, Tuomilehto J, TURDEP-II Study Group. Twelve-year trends in the prevalence and risk factors of diabetes and prediabetes in Turkish adults. Eur J Epidemiol. 2013;28(2):169-180.

11. Ergin GO, Dünder E, Ökçün S, Koçkaya G. Sosyoekonomik durumun diyabet ile ilişkisi ve diyabete etkisinin incelenmesi. Türkiye Diyabet ve Obezite Dergisi. 2020;4(2):71-78.

12. Migdalis I, Czupryniak L, Lalic N, Leslie RD, Papanas N, Valensi P. Diabetic microvascular complications. Int J Endocrinol. 2018;2018:5683287.

13. Umpierrez G, Korytkowski M. Diabetic emergencies ketoacidosis, hyperglycaemic hyperosmolar state and hypoglycaemia. Nat Rev Endocrinol. 2016;12(4):222-232.

14. Atreja A, Kalra S. Infections in diabetes. J Pak Med Assoc. 2015;65(9):1028-1030.

15. Colak B, Duran R, Can FN, Yormaz S, Zaland AW, Taşdelen E, Sarıhan ND, Arslan M, Öztürk MN, Akbaş AF, Aslan AN, Elagöz O, Lök B, Özşen Y, Ersoy C, Marakoğlu K, Şahin M. Diyabet hastalarının diyabetik ayak ülseri hakkında bilgi düzeylerinin ve ayak bakımı uygulamalarının değerlendirilmesi. Türkiye Diyabet ve Obezite Dergisi. 2020;4(1):22-29.

16. Shah BR, Hux JE. Quantifying the risk of infectious diseases for people with diabetes. Diabetes Care. 2003;26(2):510-513.

17. Kalaycı Ö, Açıkgöz B, Bayraktaroğlu T, Ayoğlu FN. Diyabetli hastaların ayak bakımı ve diyabetik ayak hakkındaki bilgi, tutum ve davranışlarının değerlendirilmesi. Türkiye Diyabet ve Obezite Dergisi. 2020;4(2):98-107.

18. Salardi S, Porta M, Maltoni G, Cerutti F, Rovere S, Iafusco D, Tumini S, Cauvin V, Zucchini S, Cadario F, d'Annunzio G, Toni S, Salvatoni A, Zedda MA, Schiaffini R, Diabetes Study Group of the Italian Society of Pediatric Endocrinology and Diabetology (ISPED). Ketoacidosis at diagnosis in childhoodonset diabetes and the risk of retinopathy 20years later. J Diabetes Complications. 2016;30(1):55-60.

19. Tanaka S, Kawasaki R, Tanaka-Mizuno S, Iimuro S, Matsunaga S, Moriya T, Ishibashi S, Katayama S, Ohashi Y, Akanuma Y, Sone H, Yamashita H. Severe hypoglycaemia is a major predictor of incident diabetic retinopathy in Japanese patients with type 2 diabetes. Diabetes Metab. 2017;43(5):424-429.

20. Kilpatrick ES, Rigby AS, Atkin SL, Frier BM. Does severe hypoglycaemia influence microvascular complications in Type 1 diabetes? An analysis of the diabetes control and complications trial database. Diabet Med. 2012;29(9):11951198 . 